\title{
LISTY WIĘZIENNE MIECZYSŁAWA ZAJEWSKIEGO PSEUDONIM „TURBACZ” (1918-1988)
}

\author{
Władysław Zajewski \\ Instytut Historii Polskiej Akademii Nauk im. Tadeusza Manteuffla \\ The Tadeusz Manteuffel Institute of History Polish Academy of Science
}

\begin{abstract}
Streszczenie. Artykuł zawiera zbiór listów żołnierza Armii Krajowej i uczestnika operacji „Ostra Brama” Mieczysława Zajewskiego ps. „Turbacz”, napisanych w latach 1949-1951 z aresztu w Łodzi oraz więzienia w Rawiczu. Można powiedzieć, że jego losy to typowa historia oficera AK. Po „wyzwoleniu" przedostał się z Litwy do centralnej Polski, a tam oskarżony został przez komunistów o działalność antypaństwową i skazany na pobyt w więzieniu. Edycję listów poprzedza wprowadzenie prof. Władysława Zajewskiego, będące jednocześnie wspomnieniem o starszym bracie. Poznajemy dzięki niemu historię życia Mieczysława Zajewskiego i jego najbliższej rodziny.
\end{abstract}

Słowa kluczowe: operacja „Ostra Brama”, represje komunistyczne w Polsce

Obrońca Wilna Mieczysław Zajewski ps. „Turbacz”, „Anglik” urodził się 17 listopada 1918 r. w Pacunelach na Litwie. W 1924 r. cała jego rodzina została administracyjnie usunięta z kraju za manifestowanie polskości i zamieszkała na Nowym Świecie w Wilnie, tuż obok kolei. Ojciec Henryk (1893-1934), inwalida wojenny, był uczestnikiem walk zbrojnych korpusu gen. Józefa Dowbora-Muśnickiego toczonych w okolicach Mińska i Bobrujska w latach 1918-1919. Sytuacja materialna rodziny pozostającej od 1934 r. pod opieką matki Anny z domu Andrzejewskiej, córki solidnego gospodarza z okolic miasteczka Turgiele, była bardzo trudna. Zmieniła ją emerytura przyznana po Henryku w 1937 r., choć wypłacana tylko przez trzy lata, do września $1939 \mathrm{r}$.

Mieczysław - najstarszy syn Henryka i Anny - ukończył w 1936 r. czteroletnią Szkołę Handlową Stowarzyszenia Kupców i Przemysłowców Chrześcijan w Wilnie.

\footnotetext{
1 Artykuł jest zmodyfikowaną i rozszerzoną wersją tekstu opublikowanego na stronie internetowej Muzeum Żołnierzy Wyklętych w Ostrołęce: W. ZAJewski, Obrońca Wilna. Mieczysław Zajewski, „Muzeum Żołnierzy Wyklętych w Ostrołęce” [online], 15 VI 2016 [dostęp: 12 IX 2019], dostępny w internecie: <https://muzeumzolnierzywykletych.pl/obronca-wilna-mieczyslaw-zajewski/>.
} 


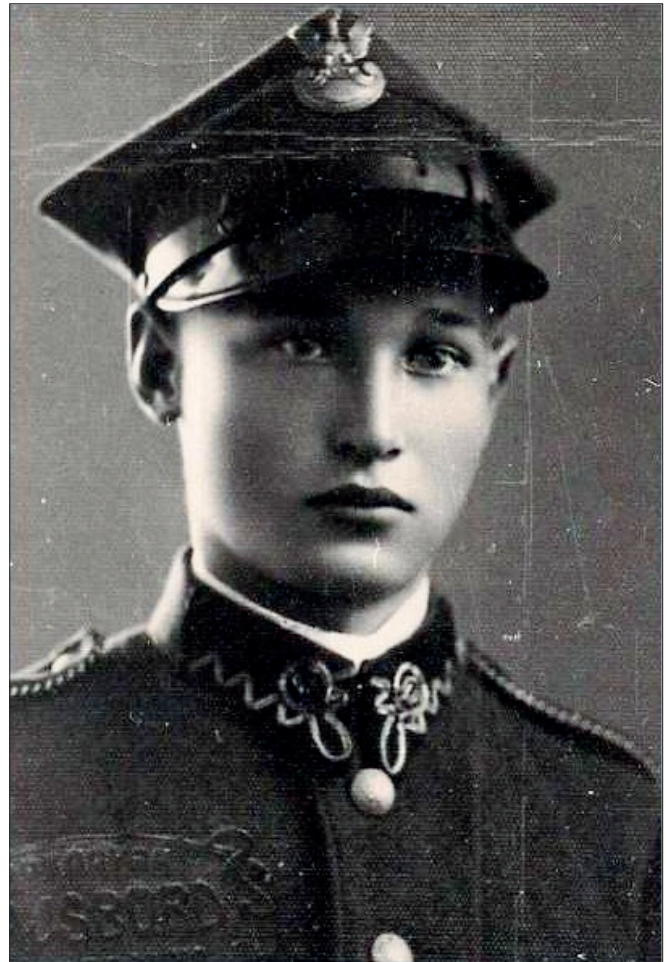

1. Mieczysław Zajewski w mundurze podchorq̨żego (1938)

W latach 1936-1937 wspólnie z kolegą Władysławem Klonowskim odbył kurs podchorążych przy 1 Dywizji Piechoty Legionów w Wilnie. W 1938 r. znalazł zatrudnienie jako pracownik umysłowy przy Magazynie Zasobów PKP, a w marcu 1939 został wysłany na praktykę do PKP w Wadowicach. W sierpniu tego roku wezwano go na ćwiczenia wojskowe, a miesiąc później wcielono do II batalionu 1 Pułku Piechoty Legionów. Uczestniczył w walkach w okolicach Pułtuska i Wyszkowa. W jego zapiskach czytamy:

Nocą, mimo dużego zmęczenia, prowadzę patrol. W jakiejś wsi mamy szukać i zbierać ewentualnych pogubionych. Rano o świcie w Wyszkowie Zatory. Niemcy nas bombardują. Trudna przeprawa przez most. Za Wyszkowem zapadamy w lasy [...] dzienny odpoczynek w wykopanych schronach. Alarm nocny, po śniadaniu wychodzimy w stronę Wyszkowa. Przyjmujemy pozycje obronne nad rzeką. Mój batalion w odwodzie. Po południu odgłosy walki. Stan pogotowia w batalionie. Kilkakrotny alarm do przeciwuderzenia. Bagnety na karabinach. Poszycie lasu pali się, dym gryzie oczy. To ręce dywersantów. Napięcie olbrzymie.

Batalion cofał się na wschód: „W dzień raczej chowamy się, nocą idziemy, i to bardzo szybko. Okrążamy Warszawę od północy. Kuchnia zaginęła. Brak posiłków. Okrutne zmęczenie". Nocą 13 września 1939 r. część batalionu zabłądziła i zamiast na Kałuszyn, pomaszerowała w stronę Garwolina: „Po zorientowaniu się batalion zmienia kierunek marszu i w najbliższej wsi trafiamy na nieprzyjaciela. Wywiązuje się walka. Wieś płonie. Ginie mój dowódca plutonu. Cały batalion idzie w rozsypkę". 17 września Mieczysław zalazł się z resztkami swojej jednostki w Lublinie. Miasto było już jednak ostrzeliwane przez Niemców, więc wycofali się z niego w nowo utworzonym batalionie. Po dwóch dniach zmuszeni byli opuścić swój pociąg, zablokowany w okolicach Zamościa. Kilka dni później, 21 września, dowódca batalionu rozwiązał formację i oznajmił swoim żołnierzom: 


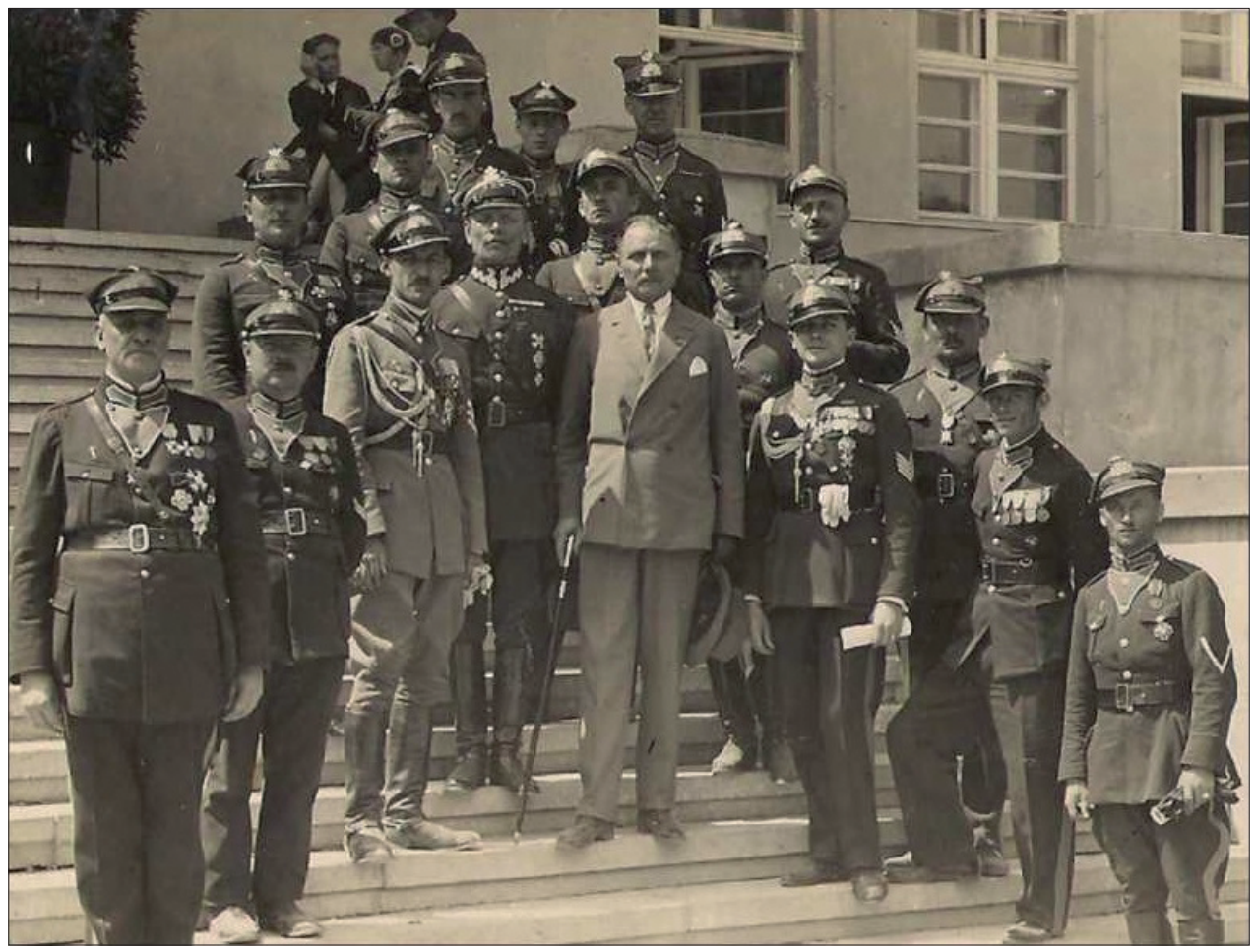

\section{Zwiq̨zek Dowborczyków z Wilna na wyciecze na Wystawę Odrodzonej Polski w Poznaniu (1925)}

Mamy wiadomość, że Warszawa broni się, ale wojska sowieckie wkroczyły na teren Polski. Od 22 do 25 września jestem więc w Hrubieszowie, noszę mundur wojskowy. Dnia 25-go września przekraczam Bug i kieruję się na wschód. Po tygodniu, w dniu 1 października, dobrnąłem do Wilna².

Przed łapanką NKWD w pociągu uratowała go polska rodzina, oświadczając, że jest ich synem. Brudny i okrutnie przemęczony dotarł następnie do rodzinnego domu przy ulicy Śniegowej.

W lipcu 1941 r. Mieczysław Zajewski rozpoczął wraz z kolegami konspirację antyniemiecką. Po latach wspominał:

Moim zadaniem było szkolenie młodszych dowódców (podoficerów), uczestnikami byli członkowie tajnych drużyn harcerskich. Ustalałem plan szkolenia i jego zakres. Przełożonych poza kolegą nie znam. Daty szkolenia i adresy otrzymuję parę dni przedtem. Orientuję się, że Włodek [Klonowski] zawiaduje całością. Ilość szkolonych w jednej grupie nie przekracza

2 Archiwum Domowe Władysława Zajewskiego [dalej: AWZ], Pisemna relacja Mieczysława Zajewskiego pt. Lata okupacyjne, b.d. (prawdopodobnie 1987 r.). 
6 osób [...]. Szkolenie prowadzę raz w tygodniu. Spotykam się początkowo z trzema grupami. Na szkolenia, w miarę przerabianego materiału, przychodzę z granatem zaczepnym, obronnym, pistoletem itp. bronią, którą otrzymywałem od Włodka. W tym też czasie dowiedziałem się, że wchodzimy w skład Armii Krajowej³.

Szkolenia i różne ćwiczenia terenowe odbywały się nad rzeką Wilią lub w okolicznych lasach. Przygotowywany przez Mieczysława Zajewskiego pluton liczący trzy drużyny harcerskie włączony został organizacyjnie do brygady kpt. Gracjana Froga ps. „Szczerbiec”.

Operacja „Ostra Brama”, zaplanowana w Komendzie Głównej AK wczesną wiosną 1944 r., doczekała się już obfitej historiografii, nie ma przeto potrzeby wyjaśniać w tym miejscu ani jej genezy, ani przebiegu ${ }^{4}$. Nadmieńmy jedynie, że całością działań miał dowodzić płk Aleksander Krzyżanowski ps. „Wilk”, mianowany w tych okolicznościach generałem brygady. Uderzenie mające doprowadzić do opanowania Wilna i utworzenia tam przedstawicielstwa legalnego Rządu RP planowano przeprowadzić 6 lipca 1944 r. dwoma zgrupowaniami Armii Krajowej - wileńskim oraz nowogrodzkim. Formalnie były to siły liczące w sumie 9-10 tys. ludzi, ale do walki stanęło zaledwie 50-55 proc. żołnierzy, niestety bez broni ciężkiej, nie mówiąc już o artylerii czy broni pancernej ${ }^{5}$.

Zbyt pochopnie zakładano wywołanie wśród Niemców paniki i szybkie wycofanie się z Wilna lub kapitulację. Historykom trudno dziś wyjaśnić ten wyjątkowo nadmierny optymizm wywiadu AK. Niedostatecznie też ocenione zostało tempo natarcia sił sowieckich, z którymi chciano współdziałać (przynajmniej w założeniach), choć nikt nie wiedział, jaki będzie ich stosunek do uzbrojonych oddziałów AK. Stacjonujący w Wilnie Niemcy dalecy były od paniki; wręcz przeciwnie - bardzo dobrze przygotowali się do twardej obrony. Z rozkazu Adolfa Hitlera nr 11 miasto miało zostać przekształcone w Fester Platz Wilna, a do kierowania jego obroną wyznaczony został wysoko ceniony sztabowiec - gen. Reiner Stahel ${ }^{6}$. Niemcy dysponowali niebagatelnymi siłami liczącymi łącznie 17400 żołnierzy i oficerów, 270 dział, 110 czołgów i wozów pancernych, 46 moździerzy i pociąg pancerny w Kolonii Wileńskiej. Od wschodu do Wilna zbliżały się potężne dywizje pancerne 3 Frontu Białoruskiego marsz. Aleksandra Wasilewskiego, które już 2 lipca 1944 r. zdobyły przyczółek nad Wilią we wsi Rybaki ${ }^{7}$.

Tempo rosyjskiego natarcia zaskoczyło gen. „Wilka”, który 4 lipca rozłożył się kwaterą we wsi Wołkorabiszki. Jeżeli chciał wykonać zadanie opanowania miasta przed sowietami, musiał podjąć decyzję działania, nie czekając na koncentra-

\footnotetext{
Tamże.

4 R. KorAB-ŻEBryK, Operacja wileńska AK, Warszawa 1985.

5 Tamże, s. 77 i nn.

6 Tamże, s. 115-127.

7 Tamże, s. 128-136.
} 


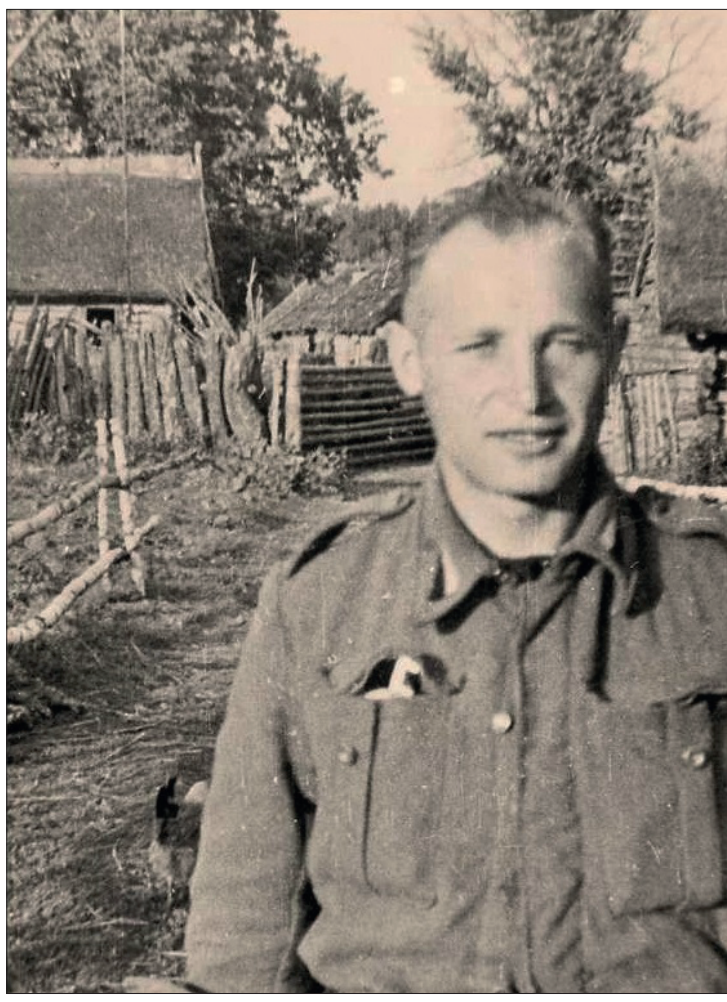

3. Mieczysław Zajewski w gospodarstwie pod Turgielami tuż przed akcja „Ostra Brama” (1944) cję wszystkich oddziałów AK. $\mathrm{W}$ istocie było to jednak niewykonalne, nie mogło być bowiem mowy o zaskoczeniu Niemców, którzy dysponowali dobrymi informacjami: ,[...] wywiad niemiecki orientował się w zagrożeniu Wilna ze strony oddziałów partyzanckich Armii Krajowej"8.

Mieczysław przyłączony został tymczasem z inicjatywy komendanta wojennego dzielnicy „D” kpt. Józefa Grzesiaka (ps. ,Kmita”, „Czarny”) do około siedmiusetosobowej brygady „Szczerbca”:

W oddziale „Szczerbca” uzyskałem prawo utrzymania plutonu w całości pod moim dowództwem. Dodano mi tylko trzech drużynowych: drużynowym I kompanii szturmowej został „Bury” (Romuald Rajs), II kompanii - „Brzoza" (Wiktor Jagoda), mój pluton oraz pluton „Joego” (Jerzy Kasprzycki) był zalążkiem III kompanii.

Od końca czerwca byli już w pełni gotowi do działania:

Na początku lipca opuszczamy zajmowane tereny za Turgielami i wyruszamy w kierunku Wilna. Maszerujemy tylko nocą. Na jednej z odpraw otrzymujemy rozkaz: przejść przez Kolonię Wileńską i wkroczyć do miasta, na wzgórze Belmont. [...] Nasze skrzydło natrafiło na pociąg załadowany wojskiem niemieckim. Znalazłem się z dwoma drużynami swego plutonu tuż przed pociągiem (8-10 metrów). Widoczność słaba. Niemcy zdecydowanie bronili się po opuszczeniu pociągu. Ginie mój zastępca, drużynowy „Środa”. Dla upewnienia się w sytuacji chciał on osobiście raz jeszcze dokonać rozeznania. Odradzałem mu, a widząc jego postanowienie, ostatecznie zgodziłem się, sugerując tylko, aby wybrał do tego celu inne miejsce niż moje. „Środa” przesunął się tylko o jakieś półtora metra w prawo, lekko wychylił się ponad rów i zginął trafiony jednym pociskiem dokładnie w serce. Ginie dwóch kolejnych dowódców kompanii. Ginie razem 18 osób. Musimy się wycofać9.

8 Tamże, s. 215.

9 AWZ, Pisemna relacja Mieczysława Zajewskiego, Relacja z okresu 7-12 lipca 1944, 14 V 1987 r., s. 11. 
Z dalszej relacji Mieczysława Zajewskiego wynika, że następnie przez dwa dni atakowali bunkry na Belmoncie, w których bronili się głównie „Ukraińcy w służbie niemieckiej":

Oddział ponosi straty, ale wszyscy Ukraińcy zginęli. W tym też czasie wychodzą z konspiracji oddziały AK w mieście, likwidują poszczególne punkty oporu ukraińskie i niemieckie. [...] Na baszcie Góry Zamkowej powiewa sztandar biało-czerwony.

14 lipca 1944 r. ppłk Adam Szydłowski ps. „Poleszuk” nadał do komendanta głównego depeszę następującej treści:

Wilno zdobyte przy znacznym udziale AK, która weszła do miasta. Duże zniszczenia i straty. Stosunki z armią sowiecką chwilowo poprawne. Rozmowy w toku. Wilno przeżyło bardzo krótką, ale jakże radosną chwilę wolności. Polskość miasta bije w oczy ${ }^{10}$.

Straty AK poniesione w bezpośrednich walkach w ramach akcji „Ostra Brama" wniosły: 189 poległych, 235 rannych oraz 12 zaginionych. Nie jest to jednak pełna liczba poległych, gdyż należałoby do niej doliczyć starty poniesione 13 lipca w walce z wycofującymi się siłami niemieckimi gen. Stahela, tj. 79 zabitych, 35 rannych i 10 zaginionych partyzantów.

Wojowanie Mieczysława Zajewskiego zakończyło się 12 lipca 1944 r. Otrzymał wówczas od Józefa Grzesiaka „Kmity” kartkę z poleceniem dołączenia do jego oddziału, który już się ujawnił, na ulicy Kalwaryjskiej. ,[...] niezwłocznie zameldowałem się u »Szczerbca « - pisze - i podałem otrzymaną kartkę. Był wyraźnie niezadowolony i do ppor. »Lota« powiedział: Przyszli bez broni, to wypuścić ich bez broni”. Jak wynika z zapisków Mieczysława, jego rozstanie ze „Szczerbcem” było dość chłodne: „Podziękowałem za służbę i wyszedłem”"1.

Już po latach, rozmawiając z Mieczysławem, odniosłem wrażenie, że główną przyczyną tego zadrażnienia było przekonanie o błędzie taktycznym popełnionym w Kolonii Wileńskiej. Chodziło o to, że dziewięć plutonów bojowych 3 brygady, mając odsłonięte skrzydła i nie dysponując bronią ciężką, nie powinno wdawać się $\mathrm{w}$ walkę z osłonowym niemieckim pociągiem pancernym, ale bezszelestnie przeskoczyć przez tory kolejowe. Wtórną, ale zapewne irytującą sprawą była dokonana przez „Szczerbca” 6 lipca 1944 r. zmiana dowódcy III kompanii z „Joego” na Henryka Iwaszkiewicza „Ojca”. Staż i doświadczenie bojowe wskazywały raczej na „Turbacza” (uczestnika wojny obronnej w 1939 r. i absolwenta kursu podchorążych), ale pewne różnice w sprawach organizacyjnych III kompanii zdecydowały

${ }^{10}$ R. Korab- Żebryк, Operacja wileńska..., s. 440.

${ }^{11}$ AWZ, Pisemna relacja Mieczysława Zajewskiego, Relacja z okresu 7-12 lipca 1944, s. 9. 
o awansie „Ojca”: „[...] nie zadawał pytań, nie miał wątpliwości. Był człowiekiem oddanym »Szczerbcowi«”. Zdaniem Mieczysława to właśnie „Ojciec” rozpoczął walkę przy pociągu. „Rozkaz rozpoczęcia ognia, a więc ujawnienia kompanii, mógł pochodzić w zasadzie tylko od dowódcy"12. Czy starcie z załogą pociągu pancernego było nieuniknione? To już inne pytanie.

Podsumowaniem służby Mieczysława Zajewskiego w Armii Krajowej Okręgu Wileńskiego jest sporządzone 25 maja 1989 r. pismo Głównej Komisji Weryfikacyjnej AK w Londynie, gdzie czytamy:

[...] podporucznik Zajewski Mieczysław, pseudonim „Anglik”, zaprzysiężony w Wilnie VIII 1941, pełnił obowiązki oficera wywiadu, od maja 1944 wcielony z plutonem „Szare Szeregi” do brygady AK „Szczerbca”, bierze udział w walkach o Wilno; przeniesiony do kompanii „Jana” walczy aż do wkroczenia wojsk sowieckich. Przyznaje: Medal Wojska i Krzyż Armii Krajowej ${ }^{13}$.

Drugi etap życia Mieczysława Zajewskiego - niestety bardziej gorzki i dramatyczny - rozpoczął się po przyjeździe do Łodzi pod koniec zimy $1945 \mathrm{r}$.

Aby wyjaśnić, jak doszło do procesu politycznego podporucznika AK, dowódcy kadrowego III drużyny plutonu szarych szeregów włączonego do 3 brygady „Szczerbca”, trzeba wyjaśnić, co działo się z Mieczysławem po 12 lipca 1944 r. Jak sam wspominał, na polecenie dowódcy kompanii kpt. „Kmity” zameldował się tego dnia u komendanta „Szczerbca”. Ich rozmowa była dość ostra. Zajewski wyraził chęć złożenia broni (po latach, które upłynęły od tych wydarzeń, myślę, że nie widział szans na militarny sukces w walce z sowiecką armią), na co „Szczerbiec” zareagował krótko, mówiąc do swego adiutanta: „Przyszli bez broni, to wypuścić ich bez broni” ${ }^{14}$. Co działo się z „Turbaczem” potem? Ujawnione kompanie, które walczyły wcześniej o Wilno - zarówno ci z bronią, jak i ci bez broni - zgromadziwszy się na placu Przycerkiewnym przy ulicy Kalwaryjskiej, otrzymały rozkaz wymaszerowania szosą „lipówką” w kierunku Miednik. Według relacji Mieczysława koło miasteczka Turgiele doszło do powtórnego spotkania z kpt. „Szczerbcem”,

${ }^{12}$ AWZ, Relacja z 14 V 1987 r., rkps, s. 11. Według Olgierda Christy jako pierwsze ogień otworzyły niemieckie czujki, które spostrzegły przedzierających się Polaków. Podważam wszakże jego opinię, że ,pociąg rzekomo pancerny to literacka przesada”, bo sam go widziałem i zwiedzałem ok. 15-16 VII 1944 r. w Kolonii Wileńskiej, gdzie stał mocno pokiereszowany na torach. Byłem w środku, zwiedziłem go, pierwsze trzy wagony były opancerzone. Możliwe, że jestem jedynym żyjącym świadkiem, który widział, dotykał i był w środku tego pociągu. Zob. O. CHRISTA, U Szczerbca i Łupaszki, Warszawa 2000, s. 106-107.

${ }^{13}$ Zaświadczenie weryfikacyjne Koła Byłych Żołnierzy Armii Krajowej, L.dz.13330/89, Londyn, $21 \mathrm{~V} 1989 \mathrm{r}$.

${ }^{14}$ AWZ, Pisemna relacja Mieczysława Zajewskiego, Relacja z okresu 7-12 lipca 1944, s. 9. 
który zapewnił go, że 3 brygada po ostatecznych ustaleniach z dowództwem radzieckim zostanie wykorzystana do walk w województwie poznańskim. „Turbacz” pozostał przy swoim zdaniu, a w nocy z 17 na 18 lipca żołnierze dowiedzieli się, że nie było żadnych ustaleń z sowietami, natomiast całe dowództwo AK, które udało się na naradę w Boguszach, zostało aresztowane! Zgromadzone pod Turgielami kompanie AK zostały niemal błyskawicznie otoczone przez radzieckie bataliony NKWD z czołgamii T-34, po czym kazano im złożyć broń i odmaszerować kolumnami na miejsce koncentracji ${ }^{15}$. „Turbacz” i kilku jego kolegów podjęli decyzję o ucieczce w nocy 18 lipca. Nazajutrz Mieczysław pojawił się u swego młodszego brata Zygmunta w Wilnie, przy ulicy Sawicz 6. We wrześniu zamieszkała tam już cała rodzina; po spaleniu naszego domu na ulicy Śniegowej dostaliśmy mieszkanie na parterze. Sytuację, w której się znaleźliśmy, najlepiej opisują chyba ostatnie słowa bohatera dramatu Antona Czechowa Wujaszek Wania: ,[...] trzeba żyć, trzeba żyć”. Mieczysław rzadko wychodził na spacery, najczęściej przesiadywał, ja natomiast stałem się głównym żywicielem rodziny, uprawiając drobny handel kopertami, papierem listowym, ołówkami itp. z żołnierzami sowieckiej armii na kolei, którą znałem jak własną kieszeń. Wiązało się z tym niestety spore ryzyko, ale to już zupełnie inny wątek losów mojej rodziny. Mieczysław późną jesienią 1944 r. załatwił sobie wcześniejszy wyjazd do Polski w ramach litewsko-polskiej umowy z 22 września, która dawała taką możliwość osobom posiadającym polskie obywatelstwo ${ }^{16}$. Rozmowa z matką była krótka: poinformował ją, że z powodu różnych okoliczności musi opuścić miasto wcześniej i spotkamy się prawdopodobnie w Łodzi, bo tam też przebywała już rodzina żony Zygmunta ${ }^{17}$. Sam Zygmunt zaciągnął się do 1 Armii Polskiej gen. Zygmunta Berlinga, bo poza Armią Czerwoną praktycznie tylko taki miał wybór, i tyle go widziałem. Mieczysław opuścił nas w listopadzie lub grudniu. W styczniu 1945 r. znalazł się w Białymstoku, a następnie po bardzo długiej i okrężnej podróży trafił do Łodzi. Udał się tam do naszej ciotki Heleny Pakć (siostry Henryka) i zamieszkał z rodziną ojca przy ulicy Wschodniej 16. Przed wyjazdem powierzyłem mu wszystkie nasze rodzinne oszczędności, w sumie ponad 20 tys. zł. Miał za nie nabyć w Łodzi locum i przygotować je na nasze przybycie.

15 J. Bogdanowicz, Trzecia Brygada Szczerbca, Armia Krajowa Okręg Wileński, wyd. 2, Warszawa 2008, s. 5; B. Krzyżanowski, Wileński Matecznik 1939-1944, Paryż 1979, s. 252; O. ChristA, U Szczerbca..., s. 115.

${ }^{16}$ Zob. A. Paczoska, Dzieci Jalty. Exodus ludności polskiej z Wileńszczyzny w latach 1944-1947, Toruń 2002; W. ZaJewski, Alicja Paczoska, „Dzieci Jatty. Exodus ludności polskiej z Wileńszczyzny w latach 1944-1947”, Toruń 2002, Wydawnictwo Adam Marszatek, ss. 414, „Universitas Gedanensis", 1(2003), s. 159-162.

17 Żona brata Zygmunta Zajewskiego (1920-1999), Jadwiga Moreńko (1923-2005) 1. voto Zajewska, 2. voto Prasał (od 1963), opuściła Wilno z rodziną swego ojczyma Kazimierza Zabojścia. On sam zamieszkał z rodziną w Łodzi, przy ul. Zgierskiej 36, na drugim piętrze, wejście tuż za bramą. 
Jeżeli jednak myślał, że wszyscy zapomnieli już o jego działalności w AK i o nim samym, to grubo się pomylił. Nie piszę tego wstępu z dokumentami w ręku; spoczywają one w archiwach Instytutu Pamięci Narodowej w Łodzi, Bydgoszczy i innych miastach. Z racji wieku piszę wyłącznie jako obserwator, członek dotkliwie represjonowanej rodziny. Już w trakcie podroży do Białegostoku Mieczysław został kompletnie okradziony z pieniędzy i dobytku; wylądował tam tylko w tym, co miał na sobie. Osobiście jestem przekonany, że od początku swojej odysei na Zachód był bardzo dobrze, bardzo dyskretnie i bardzo fachowo obserwowany. Przyjęty bez entuzjazmu przez ciotkę, podjął pracę jako administrator w Zarządzie Nieruchomości, a jednocześnie rozpoczął studia na Wydziale Ekonomicznym Wyższej Szkoły Handlowej. Ledwie zdążył zaliczyć dwa lata, kiedy rozpoczął się dramat jego i całej rodziny. $Z$ konieczności ulokowaliśmy się najpierw w mieszkaniu rodziców synowej Jadwigi, a po kilku miesiącach wegetacji otrzymaliśmy na cztery osoby jeden dwunastometrowy pokoik na trzecim piętrze. Była tam tylko kuchnia na węgiel i kran z zimną wodą, natomiast ubikację mieliśmy wspólną, na podwórzu. Zimno i warunki gorsze niż spartańskie.

Tymczasem już od 1945 r. Urząd Bezpieczeństwa Publicznego starannie przygotowywał Operację X, która miała doprowadzić do wyłapania wszystkich byłych oficerów i żołnierzy Wileńskiego Inspektoratu Armii Krajowej działających w okresie wojny, szczególnie w wywiadzie, a tam właśnie pracował Mieczysław! Ludzie, na których padł choćby cień podejrzenia, byli chwytani i poddawani torturom podczas śledztwa ${ }^{18} .25$ czerwca $1948 \mathrm{r}$. aresztowano we Wrocławiu komendanta Wileńskiego Okręgu Mobilizacyjnego AK płk. Antoniego Olechnowicza, a 29 czerwca w Łodzi - łączniczkę Reginę Sakowicz ps. „Renia”"19. Z wyjątkiem Mieczysława nikt z nas nie wiedział, że „Renia” była in spe narzeczoną mego brata! Co więcej, pod koniec maja lub na początku czerwca pod moją nieobecność

${ }^{18}$ Twarze bezpieki w PRL w latach 1944-1956, „Blogmedia 24” [online], 4 XII 2014 [dostęp: 12 IX 2019], dostępny w internecie: <http://blogmedia24.pl/node/69842>. Według innej relacji akcja represyjna pod hasłem „X” rozpoczęła się 7 VI 1947 r. Zob. także: Ośrodek Mobilizacyjny Okręgu Wileńskiego AK 1944-1948 cz. 4, „Armia Krajowa Zgorzelec (AK-NSZ-ROAK-AKO-NZW-WiN) Wirtualne Muzeum Historii Wy(za)klętej” [online], 25 VIII 2016 [dostęp: 12 IX 2019], dostępny w internecie: $<$ https://armiakrajowazgorzelec.blogspot.com/2016/08/osrodek-mobilizacyjny-okregu. html>.

${ }^{19}$ Fala aresztowań objęła ok. 6 tys. osób, z których następnie w sfingowanych procesach skazano ok. 2 tys. Zob. tamże. Akta sprawy Reginy Sakowicz (1922-2002) znajdują się w AIPN Łd, 200/67, k. 387/41 i nn. Unieważnienie wyroku w sprawie Reginy Sakowicz-Olszewskiej oraz uznanie jej za żołnierza walczącego o niepodległą Polskę zob. AIPN By, 52/28. Są to akta z roku 1996! Akt Pani Reginy Sakowicz nie badałem osobiście, ponieważ jest to dla mnie sprawa zbyt bolesna i emocjonalna. Choć w aktach oskarżenia Anny Zajewskiej i Mieczysława Zajewskiego pisano, że na procesach wystąpi świadek Regina Sakowicz, to z nieznanych mi powodów nie pojawiła się na rozprawach. Nigdy też nie spotkałem jej ani w WSR w Łodzi, ani później na wolności. 
przyniósł od niej wielką paczkę papierów nazwanych później w procesie „dokumentami poufnymi tajnej organizacji antypaństwowej”, a także pistolet należący jakoby do panny „Reni”. Ani Mama, ani ja nigdy go nie widzieliśmy. Klimat w domu robił się jakiś dziwny, więc na prośbę zaniepokojonej Mamy przejrzałem te dokumenty i jestem chyba jedynym żyjącym jeszcze ich czytelnikiem, bo zasadnie podejrzewam, że ubecy, którzy prowadzili śledztwo, ich nie czytali; nie było im to potrzebne, bo nie chodziło o ustalenie żadnej prawdy. Otóż były to rodzinne papiery pana Zygmunta Sakowicza, ojca panny Reginy, z okresu II Rzeczypospolitej: różne osobiste dokumenty świadczące o karierze pana Sakowicza w obozie piłsudczyków w Wilnie, legitymacje, pisma pochwalne, gratulacje itp. Nie było tam nic, nawet śladu jakiejkolwiek organizacji antyrządowej! Cały późniejszy zarzut był ordynarnym wymysłem ekipy śledczej łódzkiego Urzędu Bezpieczeństwa.

Wiedziony może bardziej Bożą Opatrznością niż intuicją, mimo próśb zaniepokojonej Mamy, nie udałem się do ciotki Heleny Pakć na Wschodnią 16, by szukać brata. Skończyłem właśnie znakomitą Szkołę Podstawową nr 49 przy Staszica i pomyślnie zdałem egzamin do XI Państwowego Liceum Ogólnokształcącego. Zmęczony i zatroskany, poprosiłem o pomoc naszego szkolnego prefekta ks. Stanisława Świerczka. Ten znakomity kapłan, były więzień obozu koncentracyjnego w Dachau, wysłał mnie do znajomej rodziny w Zelowie koło Łodzi. Stało się to mniej więcej po 20 czerwca 1948 r., w każdym razie po egzaminach do liceum. Z Zelowa wróciłem do Łodzi około 15-20 lipca. Pojechałem tramwajem na ulicę Zgierską 36 i gdy wszedłem na trzecie piętro, ogarnęło mnie przerażenie, bo zobaczyłem na naszych drzwiach urzędowe pieczęcie. Zapukałem do szwagierki Jadwigi, żony Zygmunta, i dowiedziałem się od niej, że wszyscy: Mieczysław, Zygmunt i Mama zostali aresztowani przez UB! Spadły na mnie wszystkie gromy z Nieba. Załamany, padłem na kolana... $Z$ dokumentów, które mam w domowym archiwum, z zachowanych kopii wynika, że Mama została aresztowana 4 lub 5 lipca 1948 r.! W akcie oskarżenia podpisanym przez chor. Mariana Stasińskiego widnieje, że „oskarżona Zajewska Anna, bardzo chytra i przebiegła, także ściśle związana z tajemnicą członków nielegalnej organizacji, czyniła różne matactwa i kłamstwa", ale w toku przesłuchań przyznała się do winy. Naturalnie chorąży nie napisał ani słowa o metodach stosowanych w śledztwie. Poznałem je z opowieści więziennych Mamy, ale gdy złożyłem zeznania przed prokuratorem IPN-u, było już za późno chor. Stasiński zdążył trafić na drugą stronę Styksu²0.

${ }^{20}$ W piśmie prokurator Beaty Marczak z 30 XI 2012 r. czytamy, że czynności procesowe „pokrzywdzonej były prowadzone przez m.in. wskazanego z nazwiska przez świadka Władysława Zajewskiego - oficera śledczego Mariana Stasińskiego. [...] W toku przeprowadzonej czynności ustalono, 
Jestem ostatnim żyjącym członkiem rodziny, który obserwował wszystkie trzy procesy przeprowadzone przed Wojskowym Sądem Rejonowym w Łodzi. Pamiętam, jak jechałem z bratem Karolem (od 1944 r. cierpiącym na zaawansowaną gruźlicę), szwagierką Jadwigą i może jeszcze kilkoma innymi osobami, ale tego nie jestem pewny. Jechaliśmy tramwajem z ulicy Obrońców Stalingradu (dawniej Legionów) kilka dobrych przystanków, a później doszliśmy pieszo do ulicy Zielonej. Po drugiej stronie jezdni stała jednopiętrowa, dość niepozorna willa z tablicą WSR. Na pierwszym piętrze przy prawie pustej sali odbyła się rozprawa Anny Zajewskiej. Niech nikt nie wyobraża sobie, że wyglądało to jak w amerykańskim filmie.

Oskarżoną Annę Zajewską wprowadzono w kajdankach, zmaltretowaną. Przywitała nas tylko bladym uśmiechem. Prokurator odczytał akt oskarżenia. Na pytanie przewodniczącego WSR obwiniona powiedziała, że nie zdawała sobie sprawy, że w przyniesionej do domu paczce były jakieś dokumenty, więc na wszelki wypadek schowała pakiet na strychu; możliwe, że w zamieszaniu coś tam nawet spaliła, ale żadnej broni nigdy nie widziała. Obrońca z urzędu wstał i poprosił o najniższy wymiar kary. Po naradzie prezydujący odczytał werdykt, w którym zgodnie $\mathrm{z}$ wnioskiem obrony wymierzył najłagodniejszą przewidzianą w kodeksie karę, czyli pięć lat bezwzględnego więzienia! Pamiętam, że jako półbezdomny licealista pisałem potem do prezydenta Bolesława Bieruta rozpaczliwe listy z prośbą o uwolnienie Matki. 29 marca 1949 r., chyba w ramach jakiejś wewnętrznej kontroli praworządności, Naczelny Sąd Wojskowy w Warszawie obradujący w składzie: płk Drohomirecki, ppłk Jan Hryckowian i ppłk Badecki unieważnił werdykt WSR w Łodzi z 17 stycznia 1949 r., stwierdzając, że art. $148 \mathrm{kk}$ WP „Zwalnia od odpowiedzialności osoby udzielające pomocy swoim najbliższym, w tym przypadku synowi przez matkę". 11 kwietnia 1949 r. wypuszczono Mamę z więzienia. Spotkałem ją nazajutrz w południe, na schodach naszej klatki. Czekała na mój powrót z liceum. Był to jeden z najszczęśliwszych dni w moim życiu!

Proces brata Zygmunta, aresztowanego 1 lipca 1948 r. w mieszkaniu ciotki Heleny Pakć, przebiegał najsprawniej i najkrócej. Odpowiadał za przyjęcie od Mieczysława pistoletu vis kal. $9 \mathrm{~mm}$ i trzynastu naboi oraz ukrycie tego w Zakładzie Stolarskim przy ul. Zawadzkiej 19. W czasie śledztwa długo odmawiał przyznania się do winy i zrobił to dopiero 8 września, po zeznaniach Mieczysława. W związku z tym, że oskarżony Zygmunt Zajewski, „z zawodu stolarz,

że Marian Stasiński zmarł w 1986 r. Do akt niniejszego postępowania załączono kserokopię aktu zgonu tego funkcjonariusza". AWZ, Postanowienie o umorzeniu śledztwa Oddziałowej Komisji Ścigania Zbrodni przeciwko Narodowi Polskiemu w Łodzi w sprawie m.in. pokrzywdzonej Annie Zajewskiej (zmarłej w 1963 roku), kopia, Beata Marczak, 30 XI 2012 r. 
bezmajętny, służył w wojsku w I pp I Dywizji Kościuszki od listopada 1944 do grudnia 1945 w stopniu szeregowego, oznaczonego Medalem za Warszawę, Odrę i Berlin i zwycięstwo nad Niemcami”, WSR wydał najłagodniejszy możliwy werdykt - dwa lata więzienia z zaliczeniem czasu spędzonego w areszcie. Praktycznie odsiedział więc po skazaniu niepełny rok ${ }^{21}$.

Główny proces Mieczysława Zajewskiego odbył się 25 czerwca 1949 r. w tej samej sali WSR. Na podstawie art. 86 kodeksu karnego Wojska Polskiego oraz art. 4 Małego Kodeksu Karnego zarzucono mu, że jako „członek nielegalnej organizacji usiłował przemocą obalić ustrój Państwa Polskiego, w tym celu posiadał nielegalnie broń palną". Za powyższe przestępstwa sąd skazał Mieczysława na pięć lat więzienia, utratę praw honorowych na dwa lata i całkowity przepadek mienia na rzecz Skarbu Państwa, ale łączna kara wynosiła sześć lat więzienia z utratą praw publicznych i obywatelskich praw honorowych na dwa lata ${ }^{22}$. Pamiętam, że po ogłoszeniu werdyktu pozwolono nam wymienić ze skazanym kilka zdań. Gdy już powiedzieliśmy sobie serdeczne słowa, Mieczysław odchodził pod eskortą skuty kajdankami, cytując słowa z Księgi Mądrości Syracha: „Aż do śmierci stawaj do zapasów o Prawdę, a Pan Bóg będzie walczył o ciebie" (Syr 4,28).

\section{POSTSCRIPTUM}

Czytanie dokumentów archiwalnych bez odpowiedniego przygotowania prowadzi na manowce, dlatego na seminariach historiograficznych i innych zajęciach specjalistycznych uczy się młodych adeptów historii sztuki krytycznego czytania dokumentów oraz badania ich autentyczności ${ }^{23}$. Listy z głębokiej nocy stalinowskiej wydają się niewinne, może nawet błahe, ale tylko dla niedoświadczonego czytelnika. Każda kartka pocztowa czy zwięzły list nosi stempel realnego, oznaczonego numerem cenzora. Bezradny więzień dopiero z czasem nabierał doświadczenia $\mathrm{i}$ jak ognia unikał słów noszących znamiona cierpienia, uciekając się do z pozoru banalnych zdań typu: „Czuję się znośnie” lub „Czuje się dość dobrze”, bo tylko takie przepuszczał cenzor.

${ }^{21}$ AIPN Łd, J.R.595/48, Akt oskarżenia przeciwko Zajewskiemu Zygmuntowi, s. Henryka z art.4 \& 1 Dekretu z dnia 13.6.1946. W górnej części dokument opatrzony jest adnotacją: „»Zatwierdzam« Naczelnik Wydziału Śledczego W.U.B.P. w Łodzi Bocheński E. kpt.”

${ }^{22}$ Zob. opis sprawy ppor. Mieczysława Zajewskiego w: AWZ, Postanowienie o umorzeniu śledztwa Oddziałowej Komisji Ścigania Zbrodni przeciwko Narodowi Polskiemu w Łodzi w sprawie m.in. pokrzywdzonej Anny Zajewskiej (zmarłej w 1963 roku), kopia, Beata Marczak, 30 XI 2012 r., s. 4-5.

${ }^{23}$ Zob. R. MARIChal, La critique des textes, w: L'Histoire et ses méthodes, ed. Ch. Samaran, Paris 1961, s. 1234-1237. 
W dramacie Seneki pt. Oktawia poirytowany Neron woła do filozofa: „Niech zginą wszyscy, których podejrzewam o zdradę”24. Epoka stalinowska namnożyła małych, drobnych i średnich paranoicznych Neronów, którzy poprzez bicie i torturowanie więźniów wyładowywali nagromadzone w sobie zło. Pierwszym stopniem w drodze do Tartaru było przesłuchiwanie aresztowanego w Urzędzie Bezpieczeństwa Publicznego. Długość pobytu w tym miejscu zależała wyłącznie od jego skłonności do współdziałania lub odporności na ból, na rozmaite wyrafinowane tortury fizyczne. Rodzina oczywiście nie otrzymywała w tym okresie żadnej korespondencji i nie miała żadnych kontaktów z aresztowanym. Jak dostrzegli niektórzy historycy zgłębiający ten temat, reżim stalinowski bardzo skutecznie rodził w ten sposób strach pokoleniowy. Taki właśnie klimat duchowego zniewolenia i fizycznego przymusu panował na ulicy Anstata w Łodzi, w głównej siedzibie Urzędu Bezpieczeństwa Publicznego ${ }^{25}$. Gdy aresztant został już odpowiednio przygotowany, sporządzenie aktu oskarżenia było tylko formalnością. Kierowano go wówczas do więzienia śledczego, gdzie biernie oczekiwał na rozprawę przed Wojskowym Sądem Rejonowym. Naturalnie podlegał wówczas wszystkim karom dyscyplinarnym, które widniały w regulaminie zakładu. Dopiero po zakończeniu procesu karnego i ogłoszeniu wyroku kierowano skazanego do konkretnego więzienia, z reguły w innym mieście lub województwie. Taki zakład karny jak w Rawiczu, gdzie osadzono Mieczysława, miał naturalnie wewnętrzny regulamin kar porządkowych, którymi penalizowano łamanie dyscypliny. Często były to sankcje bardzo dotkliwe: karcer, pobyt na zimnie bez ubrania, ciemnica. Mieczysław prosił w listach o paczki albo zasiłek pieniężny. Gromadziliśmy je nadludzkim wysiłkiem członków rodziny, ale pomagali też szlachetni i odważni ludzie. Kilka paczek własnym kosztem przygotowała i wysłała do Rawicza moja znakomita polonistka ze Szkoły Podstawowej nr 49 w Łodzi, śp. Irena Stępień.

19 września 1951 r. Mieczysław Zajewski został warunkowo zwolniony z więzienia. Wróciwszy do Łodzi, znalazł pracę w księgowości w przemyśle lnianym, ale nigdy już nie ukończył studiów. Ponieważ pozostawał w rejestrze skazanych, nie wolno mu było piastować wyższych stanowisk kierowniczych bez względu na zdolności i kwalifikacje ${ }^{26}$. W 1971 r. opublikował dwa artykuły w czasopismach

${ }^{24}$ Oktawia. Dramat z czasów Nerona, Warszawa 2001, s. 54.

${ }^{25}$ Zob. J. ZıóŁeK, Kryptonim „Pedagog” i „Zlikwidowani”. Związek Bojowników o Wolność. Tajna organizacja niepodległościowa nauczycieli z Łowicza. Moje wspomnienia, Lublin 2009; W. ZAJEWSKI, Jan Ziótek, ,Kryptonim »Pedagog« $i$ »Zlikwidowani«. Związek Bojowników o Wolność. Tajna organizacja niepodległościowa nauczycieli z Łowicza. Moje wspomnienia, Lublin 2009, Towarzystwo Naukowe KUL, ss. 146, „Universitas Gedanensis”, 40(2010), s. 251-253.

${ }^{26}$ Opinia naczelnego dyrektora Zjednoczonego Przemysłu Lniarskiego w Łodzi inż. Tadeusza Pytla z 23 IX 1972 r. oznajmiała: „Mieczysław Zajewski posiada wysokie kwalifikacje w zakresie 
fachowych: miesięczniku „Finanse” oraz „Ekonomii i Organizacji Pracy”. W 1978 r. nadano mu Złoty Krzyż Zasługi, a pięć lat później Honorową Oznakę Miasta Łodzi. Zmarł 10 października 1988 r. po bardzo ciężkiej chorobie, której nabawił się w zakładzie karnym w Rawiczu. Z powodu braku miejsca na cmentarzu katolickim, pochowany został na nekropolii ewangelickiej przy ulicy Ogrodowej w Łodzi ${ }^{27}$. Nie spełniła się jego wola, by leżeć w ukochanym Wilnie, na Rossach, obok ojca.

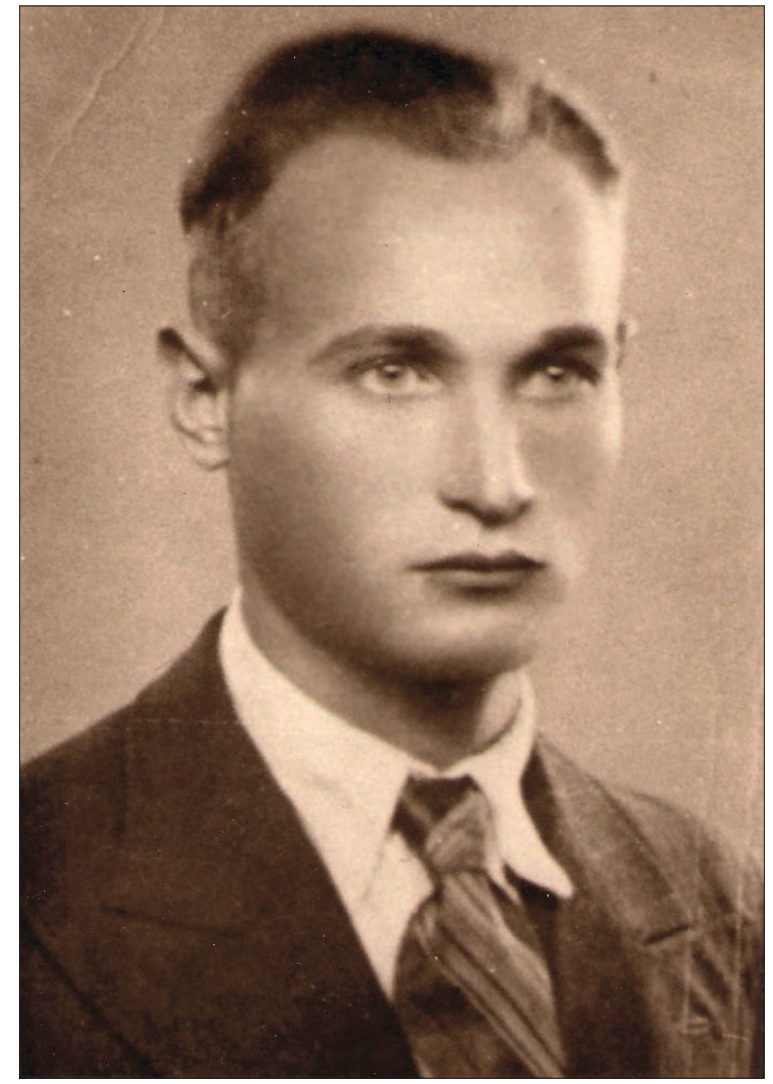

Mieczysław Zajewski (1945)

rachunkowości przemysłu i bardzo duże doświadczenie zawodowe. Jest uzdolniony, pracowity i lojalny, o dużym poczuciu odpowiedzialności i rozwagi”. Mimo to, z uwagi na obecność w rejestrze skazanych nie mógł pełnić funkcji głównego księgowego. Oryginał opinii inż. Pytla w AWZ.

${ }^{27}$ Wcześniej na skutek powikłań po grypie zmarł jego ukochany syn, Sławomir Zajewski (1958-1983), student Politechniki Łódzkiej, a później - żona Janina z d. Zborowska (1922-1988). 


\section{LISTY WIĘZIENNE MIECZYSŁAWA ZAJEWSKIEGO}

W. Pani

ZAJEWSKA ANNA

To moja pierwsza kartka. Specjalnie nie mam co do pisania. Czuję się dziś dobrze. Prosze przy przesyłaniu papierosów położyć je na tytoń. Proszę też pamiętać, że możecie do mnie pisać, i korzystajcie z tego, ponieważ otrzymanie listu $w$ moich warunkach jest rzecza wiele przyjemna.

Prosze przyjąć pozdrowienia oraz podziękowania za paczkę. Pozdrowienia znajomym.

Mietek

17.7.1949

WSR, więzień śledczy

Łódź, ul. Kopernika 29

W. Pani

\section{ZAJEWSKA ANNA}

Dziękuję za paczki. Pieniędzy dotychczas nie otrzymatem. Proszę więc pójść na pocztę i reklamować. Ja czuję się na ogół dobrze. Trapi mnie jedynie sprawa Zygmunta i choroba Karola. Proszę bardzo wystać tę kartkę do Karola lub mu napisać, to jedyny dla niego ratunek czeste przebywanie poza Łodzia. Gdyby on po wyjściu ze sanatorium mógt pozostać jeszcze w Zakopanem lub gdzieś w innym rejonie. Niech pamięta, że Łódź dla niego - to trumna. Ja w obecnych warunkach nic pomóc nie mogę. Na następne widzenie, o ile to będzie możliwe, to proszę przyjść na widzenie razem z Władkiem. Poza tym nic nie mam do powiedzenia. Proszę przesłać pozdrowienia znajomym. 
W. Pani

\section{ZAJEWSKA ANNA}

Kochana Mamo,

ostatnim widzeniem Zygma sprawił mi duża radość. Nie wiem tylko, co będzie $z$ Karolem. Jego choroba nas trapi. Władek niech się uczy i pamięta o dalszych studiach - bo chcac być człowiekiem, trzeba dużo nad soba pracować. Chciatbym, aby on przyszedt na widzenie. Zezwolenia na tran i ksiażki jeszcze nie mam. Proszę się nie martwić i nie przemęczać się, ponieważ zdrowie jest ważna rzecza. Proszę przesłać znajomym pozdrowienia. W paczkach prosze przesytać tylko to, co można, ponieważ inne dodatki konfiskuja. Jeszcze raz przesyłam pozdrowienia i catuję was.

Mietek 18.9.1949

Łódź, Kopernika 29 WSR Łódź, więzień śledczy

\section{ZAJEWSKA ANNA}

Łódź, ul. Zgierska 36/20

Kochana Mamo, wczoraj otrzymatem list Władka z września. Czuję się znośnie. Proszę przy przysłaniu paczek pamiętać, że można przysytać masło i smalec lub słoninę, smalcu $i$ stoniny razem nie można. Zreszta jest mi wszystko jedno, bo wiem, że wam nie jest lekko. Prosze przestać Karolowi pozdrowienia - to samo wszystkim znajomym. Jak się czuje Mama? Niech Władek pamięta, że już jest czas najwyższy pomyśleć o dalszych studiach, i dlatego chciatbym, aby przyszedt do mnie na widzenie. Jeszcze raz zasyłam pozdrowienia i dziękuję za paczki.

Mietek

2.10.1949

Łódź, Kopernika 29

WSR Łódź, więzień śledczy 
W. Pani

\section{ZAJEWSKA ANNA}

Kochana Mamo,

chcę na wstępie poprosić Władka, aby znalazł w mieszkaniu ksiażkę: Ludwik SELEN, Ekonomia Polityczna. Proszę tę książke przysłać mi w paczce. Inne skrypty, szczególnie EKONOMIE Polityczna prof. Oskara (Lange?), proszę na razie nie przysyłać, a tylko przygotować. Będę mógł trochę się uczyć. U mnie nic się nie dzieje ciekawego. Czuję się znośnie. Na ewentualne widzenie, jak zakończy Władek zastrzyki, to niech przyjdzie, a Mama proszę uważać na swoje zdrowie.

Przyjmijcie pozdrowienia i podziękowania za paczki. Jak się czuje Karol?

Wasz Mietek

Łódź, 16.10.1949

\section{ZAJEWSKA ANNA}

Łódź, Zgierska 36/20

Kochana Mamo,

dziękuję za otrzymane paczki. Czuję się na ogót dość dobrze. Ciekaw jestem, co się dzieje u was. Kiedy ma wrócić Karol? Czy Władek zakończyt już otrzymywanie zastrzyków? Jeżeli Wtadek będzie miat czas, to niech przyjdzie na widzenie. Niech Mama w miarę możliwości dba o swoje zdrowie. Zasyłam Wam i znajomym najserdeczniejsze pozdrowienia.

Mietek

6.11.1949

WSR, więzień śledczy Kopernika 29, wiezienie

\section{ZAJEWSKA ANNA}

Łódź, Zgierska 36/20

Kochana Mamo,

w tym tygodniu otrzymatem skrypty Ekonomii, za które serdecznie dziękuję - mam co czytać. Smuci mnie bardzo fakt choroby Mamy. Proszę, o ile tylko to możliwe, 
leczyć się i jak najmniej pracować. Gdy wróci Karol, niech napisze, jak się czuje. Ja czuję się znośnie. Mam wielki apetyt na śledzia i sądzę, że może na Święta Bożego Narodzenia zaspokoję. Prosze przyjąc serdeczne pozdrowienia i podziękowania za paczki. Pozdrowienia znajomym.

Mietek

20.11.1949

WSR, więzień śledczy

Kopernika 29

\section{ZAJEWSKA ANNA}

ul. Zgierska $36 / 20$

Kochana Mamo,

na samym wstępie chcę wam wszystkim złożyć powinszowania Świateczne i Noworoczne! Już drugie Święta spędzam samotnie, z dala od was, ale co zrobić - taka jest wola Boża. Zasmucit mnie bardzo fakt choroby Zygmunta. Jakbym chciat, aby pomyślat on o przyszłości oraz o celowości życia i żeby wreszcie zaczą dbać choć trochę o siebie. Powinien zdawać sobie sprawę, że ciasne, źle przewietrzone mieszkanie, złe odżywianie się i ciężkie łódzkie powietrze - to pierwsi jego wrogowie, $i$ do tego nieublagani. Żadnych łask i ulg pratki gruźlicy dla nikogo nie stosuja i na pewno stosować nie będa. Życzę wam wszystkim zdrowia i dobrego samopoczucia i przede wszystkim, abyście więcej dbali o swoje własne zdrowie.

Wasz Mietek

Łódź, 18.12.1949

WSR, więzień śledczy

Kopernika 29

ZAJEWSKA ANNA

ul. Zgierska 36/20

Życzenia wasze i paczkę świąteczna otrzymałem, za co serdecznie dziękuję. Otrzymatem też pieniądze. Czuję się na ogół znośnie. Martwi mnie wielce wasze ciężkie położenie materialne. Proszę pamiętać przy paczkach, że nie jestem wcale wymagajacy i gdyby byto ciężko, to zawsze zrezygnuję z nich. Proszę mi napisać, 
jak jest ze zdrowiem waszym, co stychać u Karola, Zygmunta, Władka i jak serce Mamy. Miatem dwa wrzody, ale już na szczęście się zakończyły. Kartek pocztowych miałem już za dużo i proszę mi więcej nie przesylać. Tytoniu może mi można przesyłać, o paczkę mniej papierosów. Przyjmijcie moje najlepsze pozdrowienia i podziękowania!

Wasz Mietek

Łódź, 8.1.1950

WSR, więzień śledczy

\section{ZAJEWSKA ANNA}

ul. Zgierska $36 / 20$

Kochana Mamo,

przykro jest mi niezmiernie, że w tym czasie, gdy sa tak ciężkie warunki, jeszcze ja siedze na karku, że tak powiem, waszym. O jedno proszę tylko, aby Mama ze swoim sercem nie próbowała nawet szukać pracy. Wolę zrezygnować z paczek, niż mieć świadomość, że sa płacone zdrowiem. Do Karola mam prośbę, czy mnie zrozumiat, nie wiem. Niech dba o rodzinę, jeśli tylko może, niech da choć trochę z siebie, nie tylko chęć, ale pracę. Ja nie wiem, kiedy wrócę, ale chciatbym, żeby po powrocie mógłbym mu podziękować i zrewanżować się czymś dobrym, a nie zarzutami. Proszę cię, Karolu, pamiętaj o tym. Poza tym prosze przyjąc podziękowanie za opiekę nade mna. Kartek pocztowych prosze już mi nie przesylać, tytoniu trochę mniej.

Mietek

Łódź, dn. 22.1.1950

WSR, więzień śledczy

Kopernika 29

\section{ZAJEWSKA ANNA}

ul. Zgierska $36 / 20$

Kochana Mamo,

czuję się jak zawsze na ogót dobrze. Niczego mi nie brakuje. Czas powoli mija. Źle jest mi tylko, jak myślę o Was, o tym, jak w ciężkich warunkach się znajdujecie, jak ciężko przychodzi walczyć o byt. Jest mi tym bardziej przykro, że ja do tego nieświadomie się 
przyczyniłem. Proszę szczególnie Karola, żeby on wziąt na swoja głowę czy sumienie kwestię utrzymania głównie Mamy. Wszak jest rzecza nie do pomyślenia, wprost karygodne, aby Mama ze swoimi latami, a głównie ze swoim zdrowiem, próbowała ryzyka pracy. Kto przyjmie? Proszę was, starajcie zaradzić w jakiś inny sposób. Mnie jest trudno coś poradzić, ponieważ nie znam szczegótów, ale wydaje mi się, $\dot{z}$ K Karol powinien pracować. Prosze go o to, nie chce wywierać presji, ale niech pamięta, że chciatbym z nim żyć jak z bratem. Niech on moja przeszłość daruje, a przyszłość jego zawsze mi będzie na sercu i potrafie odwzajemnić się szczerze.

Wasz Mietek

Łódź, 5.2.1950

WSR, więzień polityczny

\section{ZAJEWSKA ANNA}

ul. Zgierska 36/20

Kochani,

list Władka, a raczej dwa, otrzymatem. Cieszę się, że operacja udała się, oraz z jego postępów w nauce. Smucę się jednocześnie istniejącymi kłopotami, jak istniejacym nieporozumieniem. Władek daje piękne rady. Dziękuję, jakoś mi idzie. Chciatbym tylko, gdy będę miat widzenie za miesiąc, aby przyszedt Karol. Poza tem chciałbym was zawiadomić, że tytoniu proszę mi nie przysytać, ponieważ przestatem palić. Poza tem proszę ściśle przestrzegać przypisów przy pakowaniu paczek. Jeśli chodzi o paczkę wielkanocna, to proszę mi ja podać jak najwcześniej (bez cytrynowego proszku). Mięso może być byle jakie, nawet konina. Ja osobiście czuję się znośnie. Piszcie do mnie dwa razy w miesiacu, co słychać. Przesyłam wam życzenia Wielkanocne, życze pomyślności i zadowolenia, a Mamie zdrowia. Dziękuję za opiekę i proszę Karola, aby czasami myślat i o innych oraz aby bezwzględnie przyszedt na widzenie. Pozdrowienia znajomym i podziękowania.

Mietek

PS Do kwietnia prawdopodobnie nie napiszę.

Łódź, dn. 5.3.1950

WSR, więzień polityczny 


\section{ZAJEWSKA ANNA}

Kochana Mamo,

przed paru dniami otrzymatem list Władka i z przykrościa dowiedziatem się o chorobie Mamy. Fakt ten zasmuca mnie bardzo i gnębi, ponieważ zdaję sobie sprawę, że moje postępowanie mogło do pewnego stopnia przyczynić się do pogtębienia choroby, a w najlepszym przypadku nie zapobiegło. Jestem w sytuacji trudnej i co mogę uczynić - to tylko prosić Wszechmocnego o taskę. Życzę Wam wszystkim, a szczególnie tym, którzy nie zapominaja o mnie: wszystkiego najlepszego, a przede wszystkim zdrowia i wiele innych rzeczy. Dziwię sie poza tym, skad macie ewentualne wiadomości o mojej chorobie. To jest nieprawda. Czuję się dobrze. Przestatem palić nie dlatego, że mi zdrowie szwankuje, a jedynie $i$ wyłacznie ze względu na koszty. Nie mogę pozwolić, abyście, będac w tak ciężkich warunkach, wydatkowali się na rzeczy, bez których moge się obejść. A więc palenie na okres kary odtożyłem i palić nie będę i proszę palenia nie przysyłać.

Na zakończenie prosze przyjać moje najlepsze życzenia i pozdrowienia. Przede wszystkim zdrowia Mamie. To samo Władkowi, Karolowi i Zygmie, i Jadzi. Mam dość duży dlug wdzięczności w stosunku do Was wszystkich.

Wasz Mietek

Łódź, dn. 2.4.1950

WSR, więzień polityczny

Kochana Mamo,

jestem na nowym miejscu, czuję się dobrze. Tutaj paczki można przesytać raz jeden $w$ miesiacu, wagi wraz z opakowaniem około $7 \mathrm{~kg}$. Specjalnie ograniczeń co do ilości tluszczu, jak i cukru nie ma. Nie można tylko przysyłać chudego boczku $i$ słodkich sucharów. Proszę więc przy okazji przysłać paczkę i żeby w niej byto tluszczu okoto $2 \mathrm{~kg}$, cukru 1,5 $\mathrm{kg}$ i cebuli 1,5 kg, poza tem trochę sucharów. Ttuszcz najlepiej w dużym blaszanym kubku. To wszystko. Co do widzenia, to można jeden raz $w$ miesiacu, $w$ poniedziatki i czwartki. Prosze jednak na razie nie przyjeżdżać ze względu na znaczne koszty. Poza tem popieram zamiar Zygmunta co do wyjazdu $z$ Łodzi. Zasyłam wszystkim pozdrowienia i podziękowania. Piszcie do mnie dwa razy w miesiącu. Mój adres:

Zajewski Mieczysław, syn Henryka, urodzony 17.11.1918; Centralne Więzienie w Rawiczu, województwo poznańskie. 
Kochana Mamo,

list Władka otrzymałem - dziękuję. Czuję się na ogót dobrze. W paczce żywnościowej może być thuszczu $2 \mathrm{~kg}$ (jak będzie więcej, to też otrzymam), cebuli i czosnku (najlepiej ok. 1,5 kg), cukru 1,5 kg i trochę sucharów. Chleba nie potrzebuje. Można też przysłać tran, jeden litr miesięcznie. Ale teraz sa upaty i tran szybko nabiera przykrego zapachu. Ciesze się, ż Zygma już wyjechat, a Władek wyjedzie na kolonie. Smucę się stanowiskiem Karola w mieszkaniu i przyznam, że nie bardzo go rozumiem, choć współczuję mu w jego chorobie. Na widzenie proszę raczej nie przyjeżdżać. Z pieniędzy przeznaczonych na podróż zużyć na jedzenie lub leczenie swego chorego serca.

Pozdrowienia wszystkim.

Mietek

Więzienie Centralne w Rawiczu

Pisane: Rawicz, 5.6.1950

Kochana Mamo,

wczoraj otrzymałem paczkę - serdecznie dziękuję! Proszę tylko w następnej posypać słoninę sola i nie tak cienko krajać. Szkoda, że tak często nie piszecie, co się u was dzieje. Ja czuję się dobrze. Proszę, piszcie konkretnie dwa razy w miesiacu, bo czuje się nieprzyjemnie, gdy nie mam żadnych wiadomości. Prositbym, aby Władek, będac w ostatniej klasie, napisatby o ewentualnym wyborze zawodu. Może poradzitby mu co nie co. Posyłam wam wszystkim pozdrowienia. Pamiętajcie, że zdrowie to najcenniejsza rzecz. Życzę wam tego wszystkim. Pozdrowienia wszystkim znajomym. Piszcie!

Mietek

11.7.1950

Więzienie Centralne Rawicz

Kochana Mamo,

przede wszystkim dziękuję za paczkę, otrzymatem wczoraj. Zwracałem już uwage i jeszcze powtarzam, że gotowany boczek nie bardzo mi pasuje. Poza tem prosze nie przysylać lekarstw i witamin, mam tego dosyć, a sam się czuję dobrze. Poza tem proszę Mamy tak bardzo się nie przejmować, na razie na widzenia nie przyjeż$d \dot{z} a c ́$ - szkoda pieniędzy. Torebki, chusteczki, skarpetki, które mam - to wystarczy 
mi i więcej nie potrzebuję. Szkoda to wysyłać, bo idzie na marne. Proszę Mamy, aby starała się dbać o siebie, nie wysilać się zbytnio, tym bardziej nie nosić węgla ni kartofli. Miałem ci pomóc, Władku, w twojej edukacji. Dlatego chciałbym, abyś przy obieraniu zawodu porozumiat się ze mna. To jest waże dla nas wszystkich. Poza tem proszę, abyś postarat się dla mnie o dwie książki: pierwsza to „Logika”, zdaje mi się Jonsa (?). Miałeś tę książę pożyczona (z pewnościa trudna) i oddateś ja. Dla mnie teraz bardzo by mi się przydała. Druga ksiażka to „Psychologia”, prawdopodobnie Witwickiego (?), podręcznik szkolny, przedwojenna. Może gdzieś pożyczysz lub kupisz za pare groszy, w księgarni lub antykwariacie znajdziesz. Pamiętaj, że autorzy nie sa pewni (nie pamiętam nazwisk). Jeślibyś nie mógt znaleźć tych ksiązek - to nie przejmuj się i niech Matka o to nie kłopocze. Przyjmij więc podziękowania za starania. Przesytam wszystkim podziękowania i pozdrowienia. Witamin i tytoniu nie przesytać! Masło jeszcze mam.

Mietek

Rawicz, dn. 7.8.1950

Kochana Mamo i Bracia,

dziękuję przede wszystkim za paczkę, która dziś otrzymałem. List pisany przez Władka też dostatem. Czuję się na ogół dobrze, nic mi nie brakuje. Ksiązki, które Mama przystała, sa zapisane na mnie. Piszecie do mnie listy, ale w nich tak mato jest wiadomości. Nie wiem na przykład, jak wysoki jest Władek, ile waży; ile teraz waży Karol i jak się czuje; ile Zygma waży, ile zarabia itp. W więzieniu dopiero człowiek przekonuje się, co znaczy zdrowie. Trzeba dużo jeść. Chcę tutaj przypomnieć Wam, że jeżeli do szklanki mleka wsypie się tyżkę cukru i trochę drożdży, to po paru godzinach otrzymuje się bardzo smaczny i zdrowotny napój. Kilkadziesiąt szklanek tego i można na wadze przybyć. Pitem to, będac w szpitalu kolejowym, gdy leżatem na ischiasz. Polecam to Wam wszystkim, oczywiście o ile stać Was będzie na mleko. Władek na moje zapytanie co do ewentualnego wyboru zawodumilczy. Sądze, że odpisze mi w przyszłości. Na razie chciałbym zwrócić uwage na przedmioty przyrodnicze (biologia etc.). Poza tym dziwi mnie ten chroniczny brak czasu nawet na list. Mój Władku, nie powinieneś się przemęczać. Lekcje sq lekcjami, a parę godzin wolnego musisz mieć. Po pierwsze - dla odpoczynku; po drugie - wypoczętemu lepiej ida lekcje. Rozumiem jeszcze wasze paskudne warunki mieszkaniowe. Przyjmijcie wszyscy, tacznie z Ala i Jurkiem, moje serdeczne pozdrowienia i podziękowania za pamięć. Paczki sa dobre, prosiłbym pamiętać, że najwyższa waga do $7 \mathrm{~kg}$, bo inaczej zwrot. Gdy będzie Mama miata tran, to 
najlepiej $w$ blaszance $i$ w osobnej paczce. Jeżeli będzie w butelce, to istnieje ryzyko pęknięcia. Wiem, że tran Wam wszystkim jest potrzebny! Prositbym dodatkowo o 1-na paczkę papierosów i proszek do zębów. Nie zaszkodziłoby trochę w pigutkach żelaza do picia, lecz nie wiem, czy Mama bez recepty dostanie.

Wszystkim pozdrowienia.

Mietek

Rawicz, dn. 4.10.1950

Kochana Mamo,

list pisany przez Władka i Zygmunta otrzymatem i bardzo dziękuję. Paczkę z lekarstwami i żywnościowa otrzymatem i dziękuję. Proszę mi więcej żadnych lekarstw nie przysyłać. Można tylko witaminy oraz tran. Smucę się Waszym stanem zdrowia. Karol w sanatorium, Zygma zwolnienie otrzymuje; to chyba wystarczajace dowody na stwierdzenie, że jest nie dobrze. Napiszcie lepiej złe wiadomości niż domysty. Dbajcie o zdrowie swoje. Łódź jako miasto jest bardzo ciężkie, żeby tak gdzieś wyjechać. A teraz stare swoje sprawy. Przede wszystkim od Nowego Roku nie można przysylać paczek, a tylko pieniadze na zakup potrzebnych artykułów. W zwiazku z tym listem może jeszcze paczkę grudniowa?? Jeżeli tak, to proszę spróbować wystać na Boże Narodzenie paczkę świąteczna, może będzie można otrzymać ją. Jeżeli nie będzie można, to będzie zwrócona z powrotem. Do paczki proszę nie kłaść nic świeżego i gotowanego, bo się popsuje, a od razu wszystkiego zjeść nie można. A więc powtarzam: jeżeli będziecie mieli trochę pieniędzy (Karolowi też poślijcie), to wyślijcie normalna paczkę świateczna, ale ta ostatnia przed pierwszym stycznia. Jeżeli nie będzie można, to świateczna zwróca (6 kg). Natomiast od Nowego Roku to prositbym tylko o pieniadze. Ponieważ trochę mam pieniędzy, to można wystać aż w lutym. Proszę przyją́ moje pozdrowienia świateczne Mamie, Braciom i Znajomym. Życzę Wam wszystkim zdrowia. Caluje Was wszystkich.

Mietek

PS Pieniadze można wysyłać co miesiąc. Żadnych paczek po Nowym Roku nie będa przyjmować. 
Kochana Mamo,

ostatnio w miesiacu grudniu otrzymatem list Władka pisany w listopadzie i więcej nic. Otrzymałem też tran przed Świętami, za który bardzo dziękuję. Z paczki świątecznej nic nie wyszło - trudno. Ja osobiście czuję się jak dotychczas dobrze. Specjalnie nic mi nie brakuje. Jeżeli chodzi o widzenie - to prosiłbym, żebyście raczej nie przyjeżdzali na razie. Może lepiej odłożyć to do wiosny. Czy warto płacić tyle za droge na te pare minut widzenia się, tym bardziej że czuję się znośnie. Lepiej pieniadze te zużyjcie na siebie. Z okazji Świąt Bożego Narodzenia zasyłam wam wszystkim najserdeczniejsze życzenia, przede wszystkim zdrowia i powodzenia, catuje was wszystkich. Pozdrowienia też wysytam krewnym i znajomym. Ponieważ paczek teraz nie można przysyłać, to prosiłbym, żebyście pisali do mnie dwa razy miesięcznie, i to koniecznie. Chciałbym, żeby Zygmunt napisat, co u niego jest z płucami. Może by Karol napisat z sanatorium, jaki jest jego stan zdrowia. Wiem, że wam jest ciężko, ale co ja mogę poradzić? Żałuję, że nic nie mogę pomóc Władkowi w jego drodze życia. Mamie bardzo dziękuję za dotychczasowe paczki. Teraz będziecie mieli trochę mniej kłopotu. Mam jeszcze w depozycie około 55 zt, także dopiero w lutym, jeżeli oczywiście będziecie mieć, wyślijcie mnie parę złotych. A Mame proszę i przypominam, że lepiej zamiast widzenia kupić sobie coś do zjedzenia lub pomóżcie Karolowi. We wrześniu do was nie pisałem - wysłałem kartkę do Reginy. Przyjmijcie moje pozdrowienia i życzenia zdrowia wszystkim. Jak się ma Jadzia i jej dziadki?

Mietek Rawicz, dn. 2.1.1951

PS Paczke grudniowa otrzymatem!

Kochana Mamo,

list pisany przez Władka z końcem tygodnia otrzymatem i to wszystko. Więcej listów nie dostałem. Szkoda, że nie macie czasu pisać. Pieniadze otrzymałem i bardzo dziękuję. Prositbym was bardzo, żebyście regularnie co miesiąc, $w$ miarę oczywiście swoich możliwości, przysyłali trochę pieniędzy na wypiskę. Ja osobiście czuję się możliwie. Proszę tylko Karola, żeby brat pod uwage swój stan zdrowia i innych też. Prosze go bardzo, aby swoim postępowaniem zasłużt na zaufanie. Pamiętaj, Karolu, rzeczy chwilowe przemijające i sa rzeczy, które sa tylko zrośnięte z człowiekiem. Bądźmy lepiej braćmi, a stosunek nasz niech będzie przypieczętowany 
wyrazami życzliwości (co prawda na razie moga być tylko z twojej strony). Ciesze się, że Władek dobrze się uczy, niech jednak dba o zdrowie, bo ono jest opoka, na której można budować życie. Prositbym was, żebyście napisali, czy Regina pracuje, czy nie, bo nic o tym nie wiem.

Poza tem czuję się dobrze i prosze na razie nie przyjeżḋać. Jak jest ze zdrowiem Zygmunta? Jak wplynęła streptomycyna na zdrowie Karola? Piszcie! Całuje was wszystkich i dziękuję za pamięć i pomoc.

Mietek

Rawicz, 6.2.1951

Kochana Mamo i Bracia,

piszę kolejny miesięczny list. Nic ciekawego do zakomunikowania nie mam. Czuję się normalnie. Otrzymatem ostatnio list pisany przez Wtadka z miesiaca lutego oraz 100 zł z miesiaca marca. Tak więc ostatnio przed wypiska miatem na koncie około 230 zt. Wypiska ostatnia kosztowała czterdzieści paręzt. Wynika z tego, że posiadanych pieniędzy wystarczy na parę miesięcy. Dlatego też proszę wstrzymać się z wysytka pieniędzy przez okres miesiąca lub dwóch miesięcy. Tak mało piszecie do mnie, że nic nie wiem, co się u Was dzieje. Jak zdrowie i jak się powodzi? Prosze $w$ dalszym ciagu, żeby nikt nie przyjeżḋat do mnie, bo po prostu szkoda pieniędzy. Dbajcie o siebie. Nic nie wiem, czy streptomycyna pomogła Karolowi, czy też nie. Jak się czuje Zygma i jak jest z Mamy sercem? Czy Regina pisze? Proszę więc, przy okazji napiszcie mnie, o co proszę. No i niech Władek napisze co nieco o swoich egzaminach. A więc proszę pamiętać: pieniędzy na razie nie potrzebuję; przyjeżdżać nie trzeba; napisać dość obszerny list o sprawach domowych. Czuję się normalnie i liczę dni. Zasyłam Wam wszystkim moje najlepsze życzenia i pozdrowienia oraz podziękowanie za pamięć. Całuję Was wszystkich.

Mietek

PS Z biegiem czasu coraz wyraźniej zaznacza się, że z moim sercem jest nie za dobrze, ale na ogót czuję się dobrze. Sądzę, że w końcu maja lub na początku czerwca odwiedzicie mnie. Przed chwila wróciłem z prześwietlenia. Ptuca czyste, serce leżace i poszerzenie naczyń. A więc nic specjalnie groźnego. Ważę około $70 \mathrm{~kg}$. 
Kochana Mamo i Bracia,

przede wszystkim zawiadamiam, że otrzymatem ostatnio 60 zt i list Wtadka z 10 kwietnia. W poprzednim liście pisalem, żebyście się wstrzymali z przesytka pieniędzy przez $m$-c lub dwa. Teraz powtarzam to: przez m-c możecie zupetnie spokojnie wstrzymać się z wysytka pieniędzy. Tyle ile mam, to mi wystarczy. Poza tym prositbym, żeby ze względu na brak pieniędzy nikt nie przyjeżdżat do mnie w najbliższym czasie. W miesiacu zaś czerwcu napiszcie tak, jak do Zygmy, tylko żeby to było bez żadnych specjalnych wysitków. Ot, własna ręką. Szkoda b., że nic nie wspomnieliście o stanie zdrowia Karola. Wrócit z sanatorium, to pięknie, ale w jakim stanie? Władek wspominat o studiach. Dobrze! Gdy pisatem jesienia o tych sprawach, to nie chciat nic o tym wspominać, a teraz to nie wie, co robić, bo warunki, zainteresowania itd. Mój Władku, gdybym byt na wolności, to nie potrzebowatbyś troszczyć się o warunki materialne, ale w tej sytuacji wola jednak dużo znaczy. Droga zaś po najłatwiejszej linii oporu niewiele znaczy. W każdym bądź razie odrzucam kategorycznie wydziat humanistyczny. Na nic nie chcę namawiać (bo nie mogę nic pomóc), jeśli jednak jesteś w stanie ryzykować studia, to pomyśl o chemii, medycynie, farmaceutyce, ewentualnie leśnictwie. Może ten wydziat realizatorski, o którym wspominasz, będzie Ci odpowiadat - to proszę bardzo. Jest to pewna nowość w Polsce. Napiszcie, dokąd wyjechat Zygma. Przyjmijcie moje podziękowania i pozdrowienia i nie przejmujcie się. Na co Mama choruje, czy jak zawsze serce? Catuje Was wszystkich i znajomych.

Mietek

Rawicz, dn. 5.05.1951

Kochana Mamo i Bracia,

ja czuję się jak zawsze - normalnie. Upaty nam dokuczaja - to wszystko. Czy będe mógt pisać od siebie, tak jak to robit Zygma, to nie wiem. Jest trudno. Wy piszcie. Jeżeli chodzi o widzenie, to gdyby się Mama czuła dobrze, to prosiłbym gdzieś w sierpniu, bo wcześniej to nie ma sensu. I prositbym, żeby Mama dowiedziała się, czy można wysłać witaminy i jeśli tak, to prositbym o nie. Poza tym wszystko w porzadku - ot, czeka się. 50 zt miesięcznie na wypiskę na razie wystarcza. Otrzymałem list od Władka z 28 maja. Niech pisze o przebiegu egzaminów. Sadzę, że wreszcie zacznę otrzymywać od Was 2 listy miesięcznie, a nie tak dorywczo. Przyjmijcie podziękowanie i serdeczne życzenia powodzenia.

Wasz Mietek Rawicz, 7.06.1951 
Kochana Mamo i Bracia,

donoszę wam, że czuję się normalnie, czas mija tė̇ jak zawsze. Odczuwam tylko brak waszych listów - tak mało piszecie. Może teraz po zdaniu egzaminów przez Wtadka zabierzecie się do pisania. Poza tem prosze pamiętać i na ewentualne widzenie przyjechać tylko wtedy, gdy zajdzie ku temu potrzeba. Bo samo widzenie nic mi nie daje, a wysiłek fizyczny jest dość znaczny. Proszę więc pamiętać i starać się bez potrzeby nie przyjeżdzać. Napiszcie mi koniecznie, jak zdrowie Karola [część zdania skreślona przez cenzora].

Gdy Mama sie dowie o jego zdrowiu i o odpowiedzi na pisane podanie - to proszę mi napisać. Proszę was wszystkich, przyjmijcie moje pozdrowienia i pocatowania. Wypiska moja miesięczna nie wyniosła ostatnio 50 złotych. Jak zdrowie Mamy? Czy Zygma wyleczyt wrzody, czy Władek trafit na humanistykę?

Mietek

Rawicz, 5.7.1951

Kochana Mamo i Bracia,

czuje się normalnie i nic specjalnego nie zaszło. Ostatni list od Was dostatem w początkach lipca i dalej nic. Nie wiem, czy odma Karolowi przyjęta się i jaki jest stan Jego zdrowia. Prosze więc, napiszcie mi, i to koniecznie, jak jest z Nim. Co do Władka, to chciatbym, aby się specjalnie nie przejmowat studiami. Jak się nie uda Jemu w tym roku, to może w następnym. Losy i warunki materialne Wasze sa bardzo ciężkie i dlatego bardzo oględnie gospodarujcie. Proszę w żadnym wypadku nie pisać i nie płacić za pisanie. Pisanie Wtadka lub Mamy własnoręczne miatoby niewatpliwie taki sam skutek. Ostatnia wypiska kosztowała dwadzieścia parę zt. $Z$ tego wynika, że suma 100 zt wystarczy mi na 2 lub 3 m-ce i proszę do tego się stosować. Teraz, kiedy Karol $i$ Władek sa czasowo bez pracy, sadzę, że napiszecie mi coś więcej niż zawsze. Przyjmijcie moje podziękowania za Wasze starania i pamięć i najserdeczniejsze życzenia całej rodzinie i znajomym.

Mietek

Rawicz, dn. 30.07.1951 
Kochana Mamo i Bracia,

czuję się jak zawsze normalnie. Ostatnie upały trochę dokuczały, ale już dziś jest możliwie. Proszę usilnie na widzenie nie przyjeżdzać, bo po prostu szkoda pienię$d z y$ - nic nie ma ciekawego. Pieniędzy zaś mam na koncie już tyle, że mi wystarczy na cały rok. O następne pieniądze poprosze gdzieś w m-cu lutym, nie wcześniej. Bardzo mnie martwi stan Karola, dlatego prosze usilnie, żebyście do mnie pisali co i jak, regularnie, tzn. 2 razy w m-cu. Dziwię się bardzo, że wyjechat On nad morze. Chorym na ptuca to jak najdalej od morza. Proszę też, napiszcie, co się dzieje z Władkiem, Karolem, Zygma, Jadzia itp. W następnym miesiacu będę pisat do Reginy (otrzymatem od Niej list), także do Was nie napiszę. Chciatbym bardzo, aby Władek trafit na studia, może Mu w następnych latach będę mógt coś pomóc. Życze Wam wszystkim, a najbardziej Mamie i chorym, zdrowia i powodzenia. Catuje Was wszystkich i proszę Karola, żeby wytrzymat i miat pewność, że gdy tylko będę mógt, będę starat się Mu pomóc. Piszcie. Ostatni list Władka byt z końca czerwca, a Mame prosze, aby uważała na siebie i na najbliższych, o ile może, to niech pomoże Karolowi. Ewentualne dtugi ja przyjme na siebie. A na widzenie nie przyjeżdżać i pieniędzy nie przysyłać. Całuję Was.

Mietek

Rawicz, dn. 1.09.1951

\section{BIBLIOGRAFIA}

Archiwum Domowe Władysława Zajewskiego

Archiwum Instytutu Pamięci Narodowej w Bydgoszczy: 52/28

Archiwum Instytutu Pamięci Narodowej w Łodzi: 200/67, J.R.595/48

Bogdanowicz J., Trzecia Brygada Szczerbca, Armia Krajowa Okręg Wileński, wyd. 2, Warszawa 2008. Christa O., U Szczerbca i Łupaszki, Warszawa 2000.

KorAB-ŻEBryK R., Operacja wileńska AK, Warszawa 1985.

Marichal R., La critique des textes, w: L'Histoire et ses méthodes, ed. Ch. Samaran, Paris 1961.

Oktawia. Dramat z czasów Nerona, Warszawa 2001.

Ośrodek Mobilizacyjny Okręgu Wileńskiego AK 1944-1948 cz. 4, „Armia Krajowa Zgorzelec (AK-NSZ-ROAK-AKO-NZW-WiN) - Wirtualne Muzeum Historii Wy(za)klętej” [online], 1 V 2016 [dostęp: 12 IX 2019], dostępny w internecie: <https://armiakrajowazgorzelec.blogspot. com/2016/08/osrodek-mobilizacyjny-okregu.html>.

Paczoska A., Dzieci Jalty. Exodus ludności polskiej z Wileńszczyzny w latach 1944-1947, Toruń 2002. Twarze bezpieki w PRL w latach 1944-1956, „Blogmedia 24” [online], 4 XII 2014 [dostęp: 12 IX 2019], dostępny w internecie: <http://blogmedia24.pl/node/69842>. 
Zajewski W., Alicja Paczoska, „Dzieci Jalty. Exodus ludności polskiej z Wileńszczyzny w latach 19441947”, Toruń 2002, Wydawnictwo Adam Marszałek, ss. 414, „Universitas Gedanensis”, 1(2003), s. $159-162$.

ZAJEwski W., Jan Ziótek, „Kryptonim »Pedagog«i $i$ Zlikwidowani«. Związek Bojowników o Wolność Tajna organizacja niepodległościowa nauczycieli z Łowicza. Moje wspomnienia, Lublin 2009, Towarzystwo Naukowe KUL, ss. 146, „Universitas Gedanensis”, 40(2010), s. 253-255.

Zajewski W., Obrońca Wilna. Mieczysław Zajewski, „Muzeum Żołnierzy Wyklętych w Ostrołęce” [online], 15 VI 2016 [dostęp: 12 IX 2019], dostępny w internecie: <https://muzeumzolnierzywykletych.pl/obronca-wilna-mieczyslaw-zajewski/>.

ZióŁeK J., Kryptonim „Pedagog” i „Zlikwidowani”. Zwiąek Bojowników o Wolność. Tajna organizacja niepodległościowa nauczycieli z Łowicza. Moje wspomnienia, Lublin 2009.

\title{
PRISON LETTER OF MIECZYSŁAW ZAJEWSKI VEL "TURBACZ”
}

(1918-1988)

\begin{abstract}
The article contains a collection of letters from 1949-1951 written in the arrest in Łódź and the prison in Rawicz by Mieczysław Zajewski vel "Turbacz", a Home Army soldier and a participant of operation "Ostra Brama". His fate was typical for a Home Army officer. After the so-called liberation, he went from Lithuania to the central Poland, where he was accused by communists of anti-state activity and sentenced to prison in Rawicz. The collection of his letters is prefaced by a remembrance essay about the elder brother Professor Władysław Zajewski. The preface tells the life story of Mieczysław Zajewski and his family.
\end{abstract}

Keywords: operation "Ostra Brama", communist persecution in Poland 